\title{
Ecosystem Research Experience with Two Indigenous Communities of Colombia: The Ecohealth Calendar as a Participatory and Innovative Methodological Tool
}

\author{
Andrés Felipe SantoDomingo, ${ }^{1}$ Laura Castro-Díaz, ${ }^{1,2}$ and Catalina González-Uribe ${ }^{1,3}$ \\ ${ }^{1}$ Eje de Salud Pública, Fundación Santa Fe de Bogotá, Bogotá, D.C., Colombia \\ ${ }^{2}$ Department of Community Sustainability, Michigan State University, East Lansing, MI \\ ${ }^{3}$ School of Medicine, Universidad de los Andes, Bogotá, D.C., Colombia
}

The Wayúu Community of Marbacella and El Horno and The Barí Community of Karikachaboquira

\begin{abstract}
Eco-bio-social factors may increase or decrease a community's susceptibility to vector-borne disease transmission. Traditional studies have contributed information about the association between eco-bio-social factors and health outcomes, but few have provided this information in an integrative way characterizing annual dynamics among indigenous communities. Transdisciplinary research was conducted with the Bari of Karikachaboquira and the Wayúu of Marbacella and El Horno, using qualitative and participatory methods, including seasonal graphics, semi-structured interviews, geo-referencing routes, and participatory observation. The information was triangulated and discussed with local actors in order to validate and complement the results. An ecohealth calendar was obtained for each community, linking the socioecological dynamics to specific diseases, especially malaria. Local dynamics can change, depending on environmental conditions, and these determine the presence or absence of diseases. For both communities, the rainy season is the period with the greatest proliferation of mosquitoes (including Anopheles spp.), during which malaria cases occur. The ecohealth calendar integrates eco-bio-social information from local communities, through participatory and potentially empowering processes, into a comprehensive layout. This can break down the conceptual, demographic, and cultural barriers in the context of community-based interventions and research to action based on an ecosystem framework.
\end{abstract}

Keywords: ecohealth calendar, vector-borne diseases, social-ecological system, local knowledge, indigenous communities of Colombia, eco-bio-social

\section{INTRODUCTION}

The ecology and epidemiology of vector-borne diseases are affected by the dynamics between environmental, physical,

Published online: September 16, 2016

Correspondence to: Catalina González-Uribe, e-mail: catalina.gonzalez@fsfb.org.co biological, and socioeconomic factors (Harrus and Baneth 2005; Gage and others 2008) that occur in different spatial and temporal scales (Medina and others 2011). Environmental changes, both anthropic and natural, generate ecological disturbances that intervene in the life cycle and habitats of insect vectors, which, when added to the socioeconomics and behaviors of local populations, may 
affect the risks of transmission of vector-borne diseases (Patz and others 2000; Harrus and Baneth 2005; Paaijmans and others 2009). For example, the transmission of malaria is determined by climatic factors, behavioral patterns (such as human schedules), and workplaces (Paaijmans and others 2009). For Chagas disease, the transmission is determined by climate, inadequate housing, and human migration, as well as deforestation and growth of crop areas, which can reduce the natural habitat of triatomines. All of these can lead to an increase in vector-human contact (Guhl 2000; Abad-Franch and others 2009; Coura and Borges-Pereira 2010).

These factors and interactions do not behave in a linear manner, but rather can be presented in annual cycles (SantoDomingo 2011; Van der Hammen and others 2012) defined by seasons of the year, when the susceptibility for vector-borne disease transmission increases. Traditional studies of vector-borne diseases have contributed information about their biological, social, and health aspects, but few have provided this information in an integrative way that is adaptable for the design of community-based intervention strategies for the prevention of these diseases. In this research, we adapted the ecological calendar to the ecohealth approach as a methodological tool that integrates the local knowledge of the dynamics of eco-bio-social factors throughout a typical year. The aim of this paper was to present the experience of elaborating the ecohealth calendar with two indigenous communities in Colombia, in the context of vector-borne disease prevention, surveillance, and control, from an ecohealth framework.

\section{Methodology}

\section{Study Area}

This research was conducted in two indigenous groups in Colombia (Figure 1): the Barí community in the Karikachaboquira settlement and the Wayúu communities in Marbacella and El Horno settlements. Our research group has well established institutional collaborations to carry out public health research in both areas. We presented the project and discussed the selection of the communities with key local governmental stakeholders, and they introduced us with the communities for their informed consent.

Karikachaboquira $\left(08^{\circ} 52^{\prime} 33.1^{\prime \prime} \mathrm{N}, \quad 72^{\circ} 58^{\prime} 50.6^{\prime \prime} \mathrm{W}\right)$ is located in the indigenous reservation of Catalaura, municipality of Tibú, in the province of Norte de Santander. The ecosystem of the area consists of the Tropical
Rainforest (IDEAM and others 2007) where climate is humid, mean temperature is $27.9^{\circ} \mathrm{C}$, annual precipitation is $2.304 \mathrm{~mm}$ (PNN 2009), and annual rainfall regime is bimodal (two dry seasons and two rainy seasons). The main socioeconomic activities are agriculture, cocoa crops, fishing, and hunting.

Overall, the Barí community are more concerned about Chagas disease than malaria, because it is perceived as a silent mortal disease. In contrast, malaria is perceived as a disease with recognizable and treatable symptoms. People recognize that these diseases are transmitted by insects, which they call shidru (Triatominae, kissing bugs) for Chagas and shirakbina (Anopheles, mosquitoes) for malaria. Local health services consist of an infirmary attended by a nurse, and the nearest healthcare center requires $2 \mathrm{~h}$ of travel by river.

Marbacella $\left(11^{\circ} 30^{\prime} 24.5^{\prime \prime} \mathrm{N}, \quad 72^{\circ} 59^{\prime} 09.7^{\prime \prime} \mathrm{W}\right)$ and $\mathrm{El}$ Horno $\left(11^{\circ} 30^{\prime} 16.35^{\prime \prime} \mathrm{N}, 72^{\circ} 59^{\prime} 21.31^{\prime \prime} \mathrm{W}\right)$ are located at sea level in the rural municipality of Riohacha, in the province of La Guajira. The predominant ecosystem is Tropical Dry Forest, and arid climate (IDEAM and others 2007). The area has a mean temperature of $28.2^{\circ} \mathrm{C}$ and annual precipitation of $599 \mathrm{~mm}$ (IDEAM 2005), with an annual bimodal rainfall regime (two dry seasons and two rainy seasons). The main socioeconomic activity of these settlements is fishing, although raising livestock and artisanal work are also common. The Wayúu's knowledge about vector-borne diseases is mainly related to malaria, and health authorities are perceived responsible for control. People recognize malaria symptoms and believe that the disease is transmitted by mosquitos; however, they do not recognize Chagas disease. The triatomine (Triatoma maculata) is known as ishisü, and they identify it as an insect that "bites."

\section{Field Phase}

The field activities required for this study were developed in three stages, from February through December of 2013. The first stage included the presentation of the project, obtaining informed consent, and preliminary data collection in order to understand the eco-bio-social context of the settlements. The second stage consisted of detailed data collection with regard to ecological, biological, and social factors. Finally, the third stage included the presentation and discussion of the results with locals and key stakeholders. The required fieldwork was conducted during rainy and dry seasons, with a total of 3 visits to 


\section{STUDY AREA - COLOMBIA}

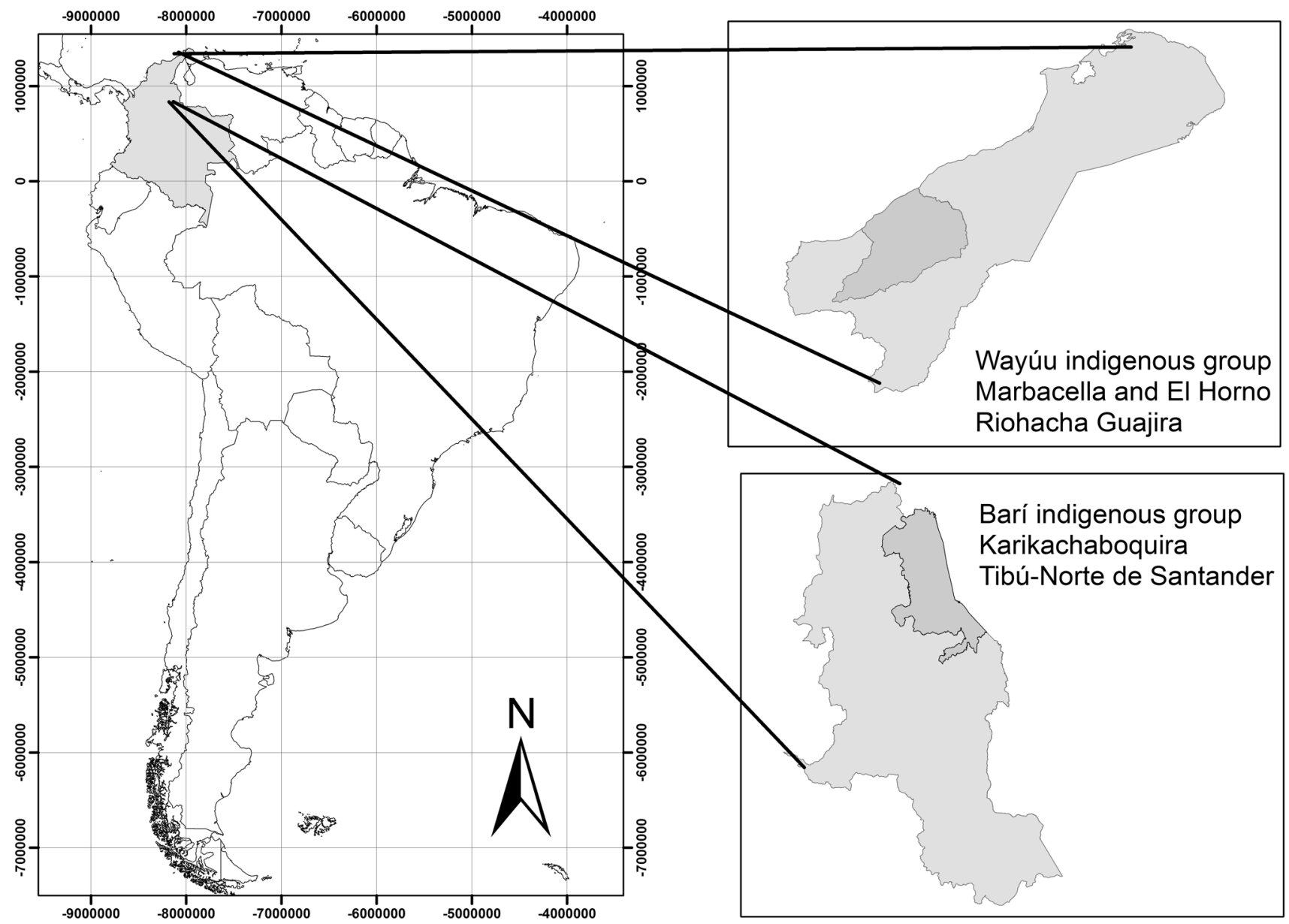

Figure 1. Location of indigenous communities

Karikachaboquira (4, 30, and 14 days), and 4 visits to Marbacella and El Horno (14, 21, 30, and 7 days).

The ecohealth calendars were constructed upon the triangulation of the information obtained with qualitative and participatory tools, using a transdisciplinary approach (Charron 2012). These were designed in order to have active participation (Geilfus 2002) from local actors and members of the Departmental Secretariats of Health (directors, technicians, entomologist, and epidemiologist).

Informal discussions, semi-structured interviews ( $N=17$ Barí, $N=8$ Wayúu) (Bonilla-Castro and Rodríguez 2005), focus groups ( $N=7$ Wayúu), and participatory workshops $(N=2$ Barí, $N=1$ Wayúu $)$ were applied. In addition, seasonal annual graphs $(N=1$ Barí, $N=2$ Wayúu) were developed in participatory workshops, using seasonal crop calendars as references (Geilfus 2002). These were built using a matrix, with local actors, com- paring the months of the year with information about climate, levels of water bodies, seasons of diseases, presence of vectors, and socioeconomic and cultural activities. The behavior of each variable throughout the year was discussed in plenary sessions. Finally, the community's consensus was written down and/or used to create symbols. Direct observation (Bonilla-Castro and Rodríguez 2005) and georeferencing routes (Victorino 2007; SantoDomingo 2011) allowed us to understand daily activities developed in each territory and complemented the information obtained using the methodological tools described above.

\section{Analytical Phase}

The data obtained were classified via previously defined categories: climatic seasonality, insect vector seasons, socioeconomic activities, sociocultural activities, demo- 


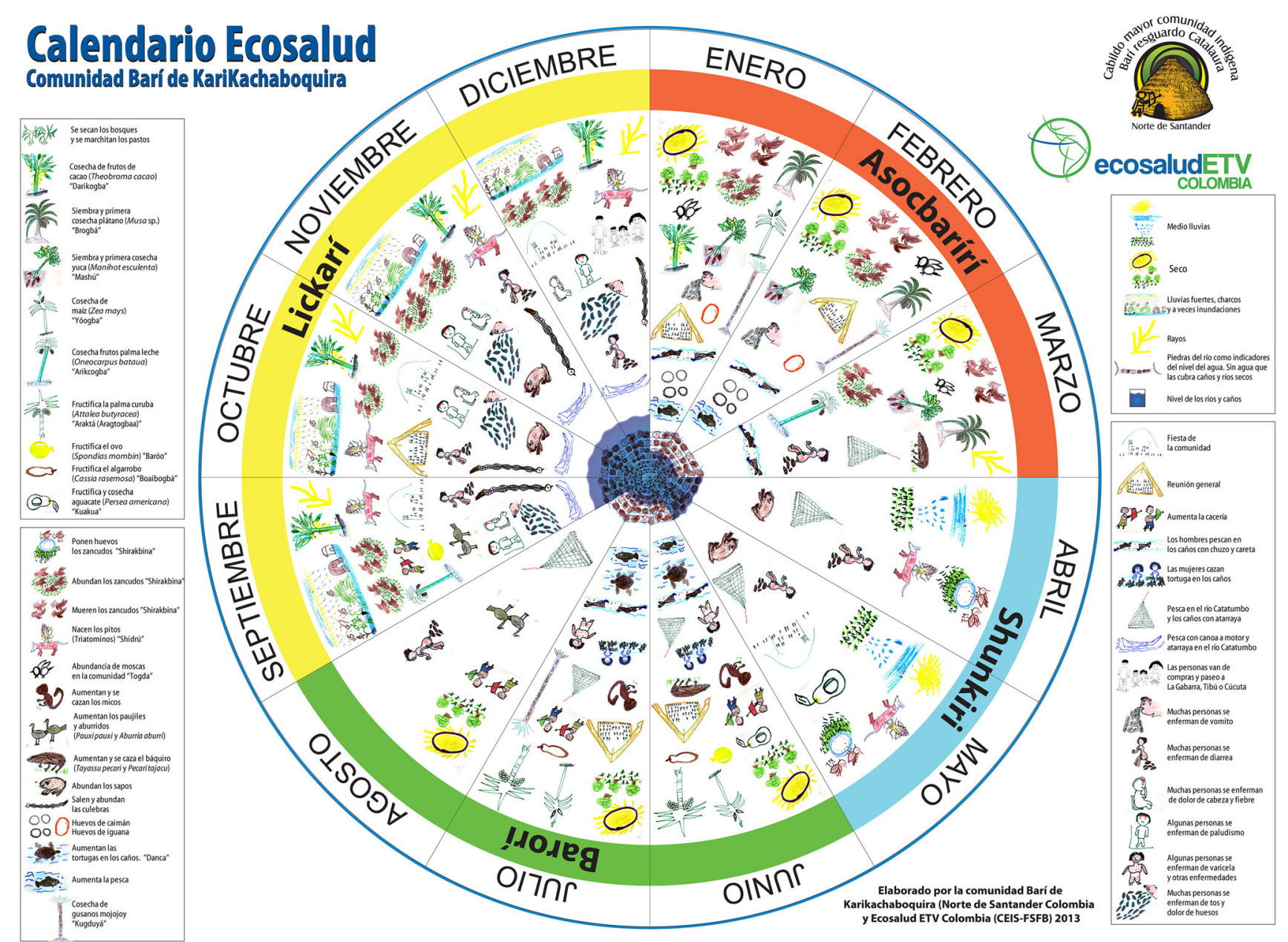

Figure 2. Ecohealth calendar-Barí community of Karikachaboquira 2013

graphic interactions, and the timing of diseases. This analytical process was validated through intra-methodological and complementary triangulation (Corujo 2003; BonillaCastro and Rodríguez 2005).

The final ecohealth calendar was plotted based on the particularities of each community. The Barí calendar was constructed using symbols that the locals drew; then, it was laid out with the help of a graphic designer. The Wayúu people preferred to share their knowledge through oral conversations. As a consequence, the Wayúu's calendar was illustrated and designed by a graphic designer and the research team, based on the information, symbols, and colors provided by the community.

\section{Presentation and Discussion Phase}

The ecohealth calendars were presented and discussed with the communities and local healthcare authorities. Recom- mendations suggested by each community were incorporated into the final version of the ecohealth calendars.

\section{Results}

Based on the collected data, one ecohealth calendar was created for the Barí community of Karikachaboquira (Figure 2), and one was created for the Wayúu communities of El Horno and Marbacella (Figure 3). Each calendar was achieved through active participation, using drawings, images, and experiential activities, in a comprehensible manner for male and female participants of all age groups, levels of literacy, and education. Both calendars portrayed the socioecological year-round dynamics along with the environmental conditions that determine the abundance of insect vectors and the prevalence of vectorborne diseases. 


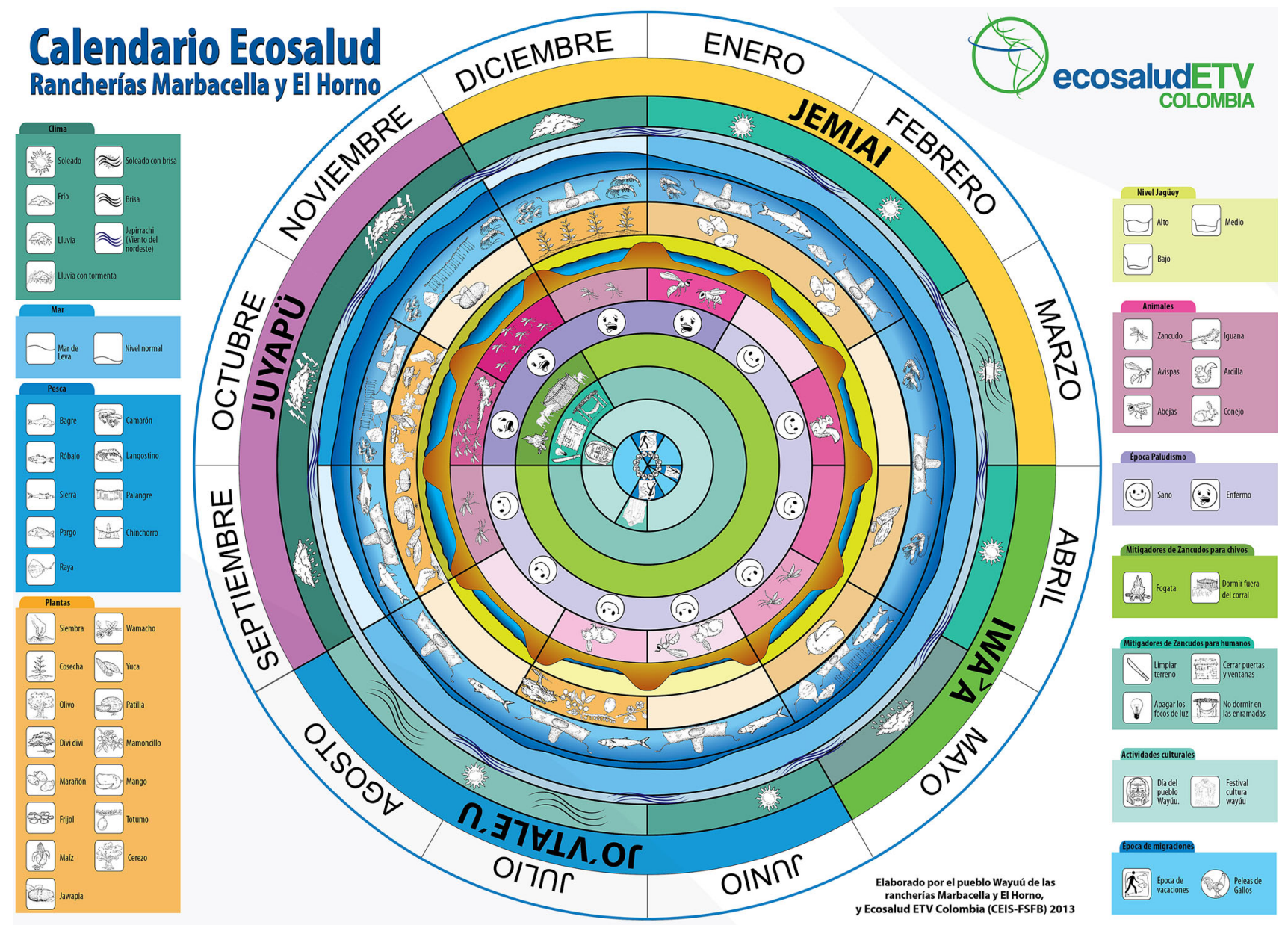

Figure 3. Ecohealth calendar-Wayúu community of Marbacella and El Horno 2013

\section{Barí Ecohealth Calendar}

For the Barí people (Figure 2), there are four seasons in the year, which are determined by rainfall and river levels. Asocbarírí (January-March) and Barori (June-August) are the seasons without rainfall, during which rivers and streams are at their lowest levels, exposing the rocks. Shunkiri (April-May) is a season with short and discontinuous rainfall, during which rivers increase their water levels up to $2 \mathrm{~m}$. Lickari (September-December) is the season during which most of the precipitation of the year occurs, bringing rivers and streams to their maximum levels.

\section{Socioeconomic Activities}

The main socioeconomic activities of this community are farming, fishing, and hunting. During the Asocbarírí season, locals from Karikachaboquira cultivate bananas (Musa spp.), cassava root (Manihot esculenta), and maize (Zea mays). The latter is harvested between September and January. During Lickari, adults harvest cocoa (Theobroma cacao) with the help of their children, who are on their end of the school-year holidays. This activity requires spending most of the day in the fields, where there is a high mosquito density and greater risk for the transmission of malaria.

Men of all ages fish with the same fishing gear in established areas throughout the year, although the water levels (which are related to the weather) determine the species and quantities caught at each location. Hunting is practiced during the day, twice per month, throughout the year. Groups of males from 7 to 50 years old, occasionally accompanied by female members, go in search of sanquí (Tayassu pecari and Pecari tajacu), armadillo (Dasypus novemcinctus and Cabassous centralis), lapa (Cuniculus paca), ñeque (Dasyprocta fuliginosa), and monkeys (mainly Alouatta seniculus). During this activity, the hunters perceive that mosquitoes bite them more often than in their houses. 


\section{Human Population Interactions}

The people from Karikachaboquira hold meetings and annual celebrations (about 90 individuals per meeting) with the inhabitants of other Barí communities and peasants. One outstanding celebration is the end of the year party in December, represented on the calendar as a hut with people (Figure 2). During this time, the community spends day and night celebrating indoors and outdoors for 2 or 3 days with people from other communities.

Animals, Vectors, and Diseases

Lickari, as noted on the calendar, is related to the yearly maximum abundance of mosquitoes, especially in the cocoa crops. During these months, the hatching of triatomines occurs.

In Shunkiri, the presence of mosquitoes and triatomines increases. It is represented on the calendar as the time when "the eggs of Anopheles hatch" and "shidru are born." It should be noted that locals feel that mosquitoes are more abundant in the agricultural fields, fallows, and forests than inside the community settlement throughout the year. Likewise, they recall individual events, such as human births, that increase the number of a particular type of mosquito.

It is evident in the calendar that the diseases recognized by the community exhibit seasonality: in January and February there are cases of vomiting; from March through May the symptoms include headaches, fever, and diarrhea; from June through August there are cases of chicken pox and "other diseases"; and from September through December cases of coughing, headaches, bone pain, fever, flu, diarrhea, and malaria have been reported. The latter is explained by the proliferation of mosquitoes, which find larval habitats during this time due to increased rainfall and river levels.

\section{Wayúu Ecohealth Calendar}

Climatic seasonality forms the basis of the Wayúu ecohealth calendar (Figure 3). Locals recognize four different seasons based on the bimodal rainfall behavior: two periods of rain per year, Juyapü from September through November and $I w a^{>} a$ from April through May; and two dry periods, Jemiai from December through March and Jo 'vtale'u from June through August.

\section{Socioeconomic Activities}

Fishing is the main socioeconomic activity in the Wayúu communities and depends on climate changes symbolized as periods of rain, sun, and breeze (Figure 3). These are accompanied year-round by northeast winds, called jepirrachi. Sea level remains constant throughout the year, with the exception of the months of September through November, when the swell arrives. This provides fishermen with greater diversity and abundance of species, such as shrimp (Caridea and Decapoda), catfish (Siluriformes), snooks (Centropomus spp.), and stingrays (Manta spp.).

Farming only occurs during rainy season (September and October), when locals cultivate short duration crops, like maize (Zea mays), watermelon (Citrullus lanatus), beans (Phaseolus vulgaris), squash (Cucurbita maxima), and melon (Cucumis melo), which are harvested two or 3 months later. Cassava (Manihot esculenta) is grown at the end of the year and is harvested in April. People attribute healing properties to herbaceous plants that grow during Juyap $\ddot{u}$ and use them to prepare Jawapias (traditional medicine).

Women cook mainly in wood stoves or on the floor; either way, it is necessary to collect firewood from the trupillo tree (Prosopis juliflora), dry cactus, and other wood, which is more abundant in the dry months (June and July). During the rainy season, wood is more difficult to find, so they collect it in areas further away from their houses.

\section{Human Population Interactions}

Human migrations are represented in the center of the calendar. Some daily activities, such as work-related travel to Riohacha, particularly by adult females who sell food in the markets, are risk factors for dengue, chikungunya, and Zika viruses transmitted by Aedes aegypti endemic to the city. Additionally, nighttime cockfighting events celebrated every 2 weeks in Marbacella and El Horno increase the risk of malaria transmission during rainy seasons, especially among adult males.

During rainy season at the end of the year (Juyapü), high migratory movements take place because of the school holidays. Communities head to and from nearby towns to be the part of the daily and nightly cultural celebrations, which occur at the time of the year with major abundance of mosquitos. 


\section{Animals, Vectors, and Diseases}

The calendar shows that the presence of wasps increases during dry months, due to the lack of water. Contrarily, during rainy months (mainly in Juyapü), people perceived an increase in the presence of mosquitoes. Most malaria cases are reported during Juyap $\ddot{u}$, and locals avoid contact with mosquitoes by closing their doors and windows early, turning off their house lights, sleeping indoors, and trimming the plants alongside their houses identified by locals as rest areas for mosquitos and snakes. Moreover, locals have reported that goats get sick from malaria, just like humans. In order to prevent illnesses in their goats during Juyap $\ddot{u}$, most residents leave them free to roam out of the yard, and set fires with cactus, buckets of eggs, and an herbaceous plant called ishisuu (Croton punctatus).

\section{Discussion}

Ecohealth calendar is a methodological tool that allows the integration and presentation of the eco-bio-social context of a community through a typical year, in an innovative and socially inclusive layout. The information collected is systematically organized into time periods with information about eco-bio-social factors that influence numerous health outcomes. Indigenous knowledge conceptualized chronologically through the calendar facilitates intercultural communication between local health authorities and researchers (Knipper 2010; Salaverry 2010). Traditional indigenous communities have a wealth of eco-bio-social information about their dependency on and adaptation to their habitats (Acosta 2001; Etter and Villa 2001; Acosta and others 2011; Reyes-Lugo and others 2011; Van der Hammen and others 2012). This information is largely unknown to outsiders, particularly decision makers, who could use the ecohealth calendar to understand how and when environmental, socioeconomic, and cultural activities fluctuate within communities and how these factors can increase susceptibility to disease, for example, transmission of vector-borne diseases in spatial scales that exceed the limits of the insect vector and/or parasite dispersion (Wesolowski and others 2012).

\section{Seasonality and Climate Change}

The climatic seasonality reported by the communities coincides with the climatic information provided by the official records for each location (IDEAM 2005). Both ecohealth calendars highlighted the rainy season at the end of the year as the moment of the highest susceptibility to vector-borne disease transmission due to vector presence and demographic dynamics; Wayúu people participate in activities such as cockfighting and cultural celebrations, while the Barí have their end of the year celebration.

In the case of Chagas disease, it has not been related to any specific time of the year in the Wayúu communities because of its asymptomatic nature (World Health Organization 2002; Coura and Borges-Pereira 2010), yet it may be related to the health imaginary of the Wayúu people. Despite recognizing the presence of the insect inside their homes, and that it bites, they do not recognize the disease currently or historically. The use of the ecohealth calendar may contribute to the identification of risk periods for diseases such as Chagas, for which seasonality may be less obvious. In this context, further ecosystem research studies could focus on the human interactions and vector activity recognized by the community.

In contrast, in the Bari ecohealth calendar, the dynamics of the triatomine population have been described. It is important to clarify that Chagas disease is a heartfelt disease for the Barí, and this may explain why people recognize, in detail, the time of the year that the triatomine population increases. Other studies in Colombia report that triatomines populations increase during dry season (Romaña and others 1999; Vásquez and others 2013). Contrarily, in the Barí calendar, as reported by Valdez-Tah and others (2015) for a community in Mexico, people mention that triatomines density increases during rainy seasons, when people are more vulnerable to transmission due to demographic dynamics, which may determine periods of higher risk (OSMAN 2012). This difference in Karikachaboquira may be due to triatomines breeding in wild habitats during dry season and house invasion by flying adult triatomines attracted by artificial light during rainy season (Vásquez and others 2013; JácomePinilla and others 2015).

Further studies could enquire about the symptoms, therapeutic itineraries, and beliefs toward chronic ailments, in contrast with infectious diseases, which, by nature, have a clearer clinical presentation and differential disease risk perception, using ecohealth calendars to identify the groups at risk within a community. For example, the calendars could be used to compare male and female activities in different age groups. 
With respect to malaria, the rainy season at the end of year is the time of the greatest proliferation of mosquitoes (including Anopheles spp.) and also a period of increased demographic interactions as mentioned above, and hence, the risk of contracting malaria increases, even at small scales (Lafferty 2009; Yukich and others 2013). In both communities, this season was reported as the moment with the highest incidence of malaria, which was validated by the Departmental Secretariat of Health of La Guajira. These findings coincide with the well-studied association between climate and malaria worldwide (Dery and others 2010; Afrane and others 2012; MacLeod and Morse 2014). The layout of this information is relevant for governmental health decision makers to anticipate and plan disease prevention, control, and surveillance programs.

This aspect is particularly important in the context of climate change. For example, changes in seasonal patterns affect human activities (e.g., water storage practices) that impact local ecology (e.g., breeding sites) and may predict higher prevalence in mosquito-borne diseases (Reiter 2001; Dery and others 2010; Afrane and others 2012; GarcíaBetancourt and others 2015). The leading role of annual seasonal weather variation on vector-borne diseases epidemiology has been extensively defined and documented. Vector populations, host reservoirs, human behavior, and practices change from season to season, interacting in complex ways and determining outbreaks (Githeko and Lindsay 2000; Gage and others 2008; Dery and others 2010; Epstein 2010; Afrane et al. 2012). The ecohealth calendar, as a stationary and multidisciplinary tool, provides snapshots of these factors to track and predict changes in seasonal patterns and hence in human activities correlated with higher incidence of risk factors for vector-borne diseases or other health outcomes. Global climate change disturbs the components that determine the epidemiology of vector transmitted diseases (Githeko and others 2000; Gage and others 2008; Lafferty 2009; Epstein 2010; Afrane and others 2012). While temperatures affect the potential ranges of diseases, weather affects the timing, intensity, and location of outbreaks (Epstein 2010). In this context, the ecohealth calendar could be used as community-based monitoring tools; communities can elaborate an annual calendar, registering changes in eco-bio-social factors and health outcomes of local importance, as a consequence of the climate change.

\section{Ecosystem Research in Practice}

In order to achieve effective prevention measures, it is crucial to understand the local context (Launiala and Kulmala 2006). The use of ecohealth calendars in applied research provides decision makers with timely information to strategically plan and focus their actions and resources on specific seasons, with potentially higher benefits for the affected community, particularly in the financially strapped settings abundant in Colombia and similar regions ( $\mathrm{Ra}-$ mirez-Hita 2014). In these communities, malaria prevention efforts must be concentrated before the end of the year, so they can be effective, as well as temporally, socially, and economically sustainable, avoiding unnecessary costs and efforts during the times of the year that they are not required.

In the same way, these efforts should integrate the knowledge and strengths of the local people through local empowerment, with regard to perceived problems and possible solutions. For the Barí people, the sense of teamwork and the importance of vector-borne diseases in their imaginary are key elements in the design of community strategies seeking general welfare. For the Wayúu people, who collectively report the need for disease prevention in their cultural imaginaries, these strategies can be focused at the family level, safeguarding prevention and not just disease control. The calendar also reflects the forms of social capital in each community that could be used in favor of the community-based intervention strategies, such as community work in Karikachaboquira and collective mitigation activities among the Wayúu to avoid mosquitoes (Waleckx and others 2015).

The calendars allowed this research team to conceptualize, through systems thinking, the socioeconomic and sociocultural activities with environmental and ecological variables, which were already recognized by the community and other stakeholders. This integration and the importance of such interactions were not related graphically before this research. Therefore, the ecohealth calendar is a tool that could be fed constantly by the local actors and researchers within the communities, the health secretaries, and through further research. This could include other categories and variables that the actors perceive to be necessary for making healthcare decisions, as well as other issues within their communities. In this way, the calendar can continually evolve. 


\section{Innovative Tool for Health Research}

The ecological calendar is a versatile research tool for conducting ecohealth research. Given its plasticity and adaptability to various thematic and socioecological contexts (Van der Hammen and others 2012), it can be used to describe the annual cycle of complex and dynamic systems (Holling 2001) that may determine or affect the transmission of any disease. This tool was adapted to the ecohealth approach and named the ecohealth calendar because it "connects ideas of environmental and social determinants of health with those of ecology and systems thinking in an action-research framework" (Charron 2012, p. 6).

On the one hand, the methodological design of the calendar takes into account various categories and their relationships as drivers of vector-borne diseases (Systems Thinking). This includes the perspectives of different stakeholders, through the elaboration of the calendar and the implementation of various tools (Transdisciplinary Research). It is based on local knowledge, and the elaboration generates an exchange of knowledge among the participants, actively involving them and resulting in an empowering process (Participation) (Charron 2012).

The resulting calendar also identifies susceptible activities and groups (Gender and Social Equity); characterizes the styles and livelihoods of the communities, in order to implement intervention activities that correspond to the socioecological context (Sustainability); and generates an integrative picture of the socioecological dynamics of the communities. Because of the didactic nature of the calendar, it has the potential to be used as an intercultural (Salaverry 2010) visual tool by local actors and decision makers (Knowledge for Action) (Charron 2012) to describe and act upon the different ecosystem, cultural, and socioeconomic characteristics.

\section{Empowerment Tool}

Most importantly, the ecohealth calendar allowed the research team (during fieldwork) to cut across the social barriers between the indigenous communities, government stakeholders, and healthcare technicians. Social inclusion was achieved through the use of the calendar, regardless of age, gender, formal education, and language. Moreover, the graphics and layout broke down the language, gender, literacy, age, culture, and conceptual barriers. The use of drawings and images was comprehensible by the participants in all age groups, independent of their native tongue or literacy and formal education levels. More importantly, it involved active participation with no gender restriction, since it did not involve traditionally male- or female-oriented roles. During the construction of the calendar, and afterward, as a synthetic visual information tool to present and discuss health and life issues, the ecohealth calendar provided an opportunity for locals to express their voice in the decision-making processes. Additionally, it provided a clear way for them to empower themselves, with respect to the prevention, vigilance, and surveillance of vector-borne diseases as presented in this research, which is applicable to other health issues. Furthermore, an ecohealth calendar has the potential to serve as a tool for intercultural dialogue in the context of research conducted with indigenous communities, and among culturally diverse populations (Spiegel and others 2011).

\section{CONCLUSION}

The ecohealth calendar is an innovative methodological tool to conduct transdisciplinary, participatory research from an ecosystems framework, which is particularly suitable for research among culturally diverse groups. It allows the integration of eco-bio-social factors in a layout that breaks conceptual and cultural barriers. In addition, it can be tailored to provide sufficient information for the design of comprehensive strategies that link eco-bio-social information from the perspectives of the local actors and stakeholders. These should be taken into account for the implementation and effectiveness of health intervention strategies based on an ecohealth framework.

\section{ACKNOWLEDGEMENTS}

This paper would not have been possible without the hard work and dedication of the families that welcomed our research team in the Barí community of Karikachaboquira and in Marbacella and El Horno settlements of the Wayúu people. We acknowledge the support and contributions of the members of the Departmental Health Secretariats of Norte de Santander and La Guajira. We also thank the IDRC (International Development Research Centre) and COLCIENCIAS (Administrative Department of Science, Technology, and Innovation) who funded the project "Intercultural design and implementation of an eco-biosocial research initiative with two indigenous communities 
in Colombia" in the year 2012 to the Public Health Axis of Fundación Santa Fe de Bogotá, Colombia.

\section{REFERENCES}

Abad-Franch F, Monteiro FA, Jaramillo ON, Gurgel-Gonçalves R, Dias FBS, Diotaiuti L (2009) Ecology, evolution, and the long-term surveillance of vector-borne Chagas disease: a multi-scale appraisal of the tribe Rhodniini (Triatominae). Acta Tropica 110(2-3):159177. http://doi.org/10.1016/j.actatropica.2008.06.005

Acosta. (2001) Los sistemas de producción de la etnia Ticuna del resguardo Puerto Nariño, Sur del trapecio amazónico, una aproximación. Cuadernos de Desarrollo Rural, 46, 101-132.

Acosta L, Pérez M, Juragaro L, Nonokudo H, Sánchez G, Zafiama Á, Tejada JB, Cobete O, Efaiteke M, Farekade J, Giagrekudo H, Neikase S (2011) La chagra en La Chorrera: más que una producción de subsistencia, es una fuente de comunicación y alimento físico y espiritual, de los Hijos del tabaco, la coca y la yuca dulce. Los retos de las nuevas generaciones para las prácticas culturales y los saberes tradicionales asociados a la biodiversidad. Instituto Amazónico de Investigaciones Científicas, Sinchi. Asociación Zonal Indígena de Cabildos y Autoridades Tradicionales de La Chorrera - AZICATCH.

Afrane YA, Githeko AK, Yan G (2012) The ecology of Anopheles mosquitoes under climate change: case studies from the effects of deforestation in East African highlands. Annals of the New York Academy of Sciences 1249(1):204-210. http://doi.org/10. 1111/j.1749-6632.2011.06432.x

Bonilla-Castro E, Rodríguez P (2005) Más allá del dilema de los métodos: la investigación en las ciencias sociales, de los Andes U (editor). Norma.

Charron DF (2012) Ecohealth: origins and approach. In: Ecohealth Research in Practice. Innovative Applications of an Ecosystem Approach to Health, Charron DF (editor) (pp 1-30), Ottawa: International Development Research Centre. http://doi.org/10. 1007/978-1-4614-0517-7

Corujo B (2003) Metodología de la investigación científica: Triangulacion en Investigacion, Facultad de ciencias de la Salud: Universidad Nacional de Entre Rios

Coura JR, Borges-Pereira J (2010) Chagas disease: 100 years after its discovery. A systemic review. Acta Tropica 115(1-2):5-13. http://doi.org/10.1016/j.actatropica.2010.03.008

Dery DB, Brown C, Asante KP, Adams M, Dosoo D, Amengaetego S, Wilson M,Chandramohan D,Greenwood B, OwusuAgyei S (2010) Patterns and seasonality of malaria transmission in the forest-savannah transitional zones of Ghana. Malaria Journal 9(314):1-8. http://doi.org/10.1186/1475-2875-9-314

Epstein P (2010) The ecology of climate change and infectious disease: comment. Ecology 3(91):925-928. http://doi.org/10. 1890/09-0761.1

Etter A, Villa LA (2001) Los sistemas de producción, extracción y asentamiento en el análisis de la transformación del paisaje. In: Ponencia seminario internacional: transformación de ecosistemas; análisis y gestión.

Gage KL, Burkot TR, Eisen, RJ, Hayes EB (2008) Climate and vectorborne diseases. American Journal of Preventive Medicine 35(5):436-450. http://doi.org/10.1016/j.amepre.2008.08.030

García-Betancourt T, Higuera-Mendieta DR, González-Uribe C, Cortés S, Quintero J (2015) Understanding water storage practices of urban residents of an endemic dengue area in Colombia: perceptions, rationale and socio-demographic characteristics. Plos One 10(6):1-19. http://doi.org/10.1371/journal. pone. 0129054

Geilfus F (2002) 80 herramientas para el desarrollo participativo: Diágnostico, planificación, monitoreo y evaluación, San José, Costa Rica: IICA

Githeko AK, Lindsay SW (2000) Climate change and vector-borne diseases: a regional analysis. Bulletin of the World Health Organization 78(9):1136. Retrieved from http://search.ebsco host.com/login.aspx?direct $=$ true $\& \mathrm{db}=\mathrm{eih} \& \mathrm{AN}=3556655 \&$ lang $=$ es\&site $=$ eds-live

Githeko AK, Lindsay SW, Confalonieri UE, Patz JA (2000) Climate change and vector-borne diseases: a regional analysis. Bulletin of the World Health Organization 78(9):1136-1148

Guhl F (2000) Enfermedad de Chagas o Tripanosomiasis Americana. Situación actual en Colombia. Revista Medicina 22(2 (53)):89-95.

Harrus S, Baneth G (2005) Drivers for the emergence and reemergence of vector-borne protozoal and bacterial diseases. International Journal for Parasitology 35(11-12):1309-1318. http://doi.org/10.1016/j.ijpara.2005.06.005

Holling CS (2001) Understanding complexity of economic, ecological, and social systems. Ecosystems 4(5):390-405. http://doi. org/10.1007/s10021-001-0101-5

IDEAM (2005) Atlas climatológico de Colombia, Bogotá: Instituto de Hidrología, Meteorología y Estudios Ambientales IDEAM

IDEAM, IGAC, IAvH, Invemar, Sinchi I, IIAP. (2007) Ecosistemas Continentales, Costeros y Marinos de Colombia. Bogotá: Instituto Geográfico Agustín Codazzi.

Jácome-Pinilla D, Hincapie-Peñaloza E, Ortiz MI, Ramírez JD, Guhl F, Molina J (2015) Risks associated with dispersive nocturnal flights of sylvatic Triatominae to artificial lights in a model house in the northeastern plains of Colombia. Parasites \& Vectors 8(1):600. http://doi.org/10.1186/s13071-015-1209-3

Knipper M (2010) Beyond the indigenous: health and interculturality at the global level. Revista Peruana de Medicina Experimental Y Salud Pública 27(1):94-101

Lafferty K (2009) The ecology of climate change and infectious diseases. Ecology 90(8):888-900. http://doi.org/10.1890/07-1861. 1

Launiala A, Kulmala T (2006) The importance of understanding the local context: women's perceptions and knowledge concerning malaria in pregnancy in rural Malawi. Acta Tropica 98(2):111-117. http://doi.org/10.1016/j.actatropica.2005.12.008

MacLeod D, Morse A (2014) Visualizing the uncertainty in the relationship between seasonal average climate and malaria risk. Scientific Reports 4:7264. http://doi.org/10.1038/srep07264

Medina D, Bevilacqua M, Cárdenas L, Morales LG, Rubio Y, Martínez A, Behm V, Moreno J, Magris M (2011) Mapa de riesgo de transmisión de malaria en la cuenca del río Caura, Venezuela Risk map of malaria transmission in the Caura river basin, Venezuela. Boletín de Malariología y Salud Ambiental, Li N 2:129-144.

OSMAN. (2012) Cambio climático II: Fauna y vectores. Junta de Andalucia, Unión Europea, Observatorio de Salud y Medio Ambiente de Andalucia.

Paaijmans KP, Read AF, Thomas MB, Singer BH, Readab AF (2009) Understanding the link between malaria risk and climate. Proceedings of the National Academy of Sciences of the United States of America 106(33):13844-13849 
Patz JA, Graczyk TK, Geller N, Vittor AY (2000) Effects of environmental change on emerging parasitic diseases. International Journal for Parasitology 30(12-13):1395-1405.

PNN. (2009). Plan de manejo Parque Nacional Natural Catatumbo Barí. http://www.parquesnacionales.gov.co/portal/wp-content/ uploads/2013/12/PlandeManejoPNNCatatumboBari.pdf

Ramirez-Hita S (2014) Health, globalization and interculturalism: an anthropological approach to the situation of indigenous peoples in South America. Ciência \& Saúde Coletiva 19(10): 4061-4069

Reiter P (2001) Climate change and mosquito-borne disease. Environmental Health Perspectives 109(Suppl. 1):141-161. http://doi.org/10.2307/3434853

Reyes-Lugo M, Reyes-Contreras M, Salvi I, Gelves W, Avilán A, Llavaneras D, Navarrete LF, Cordero G, Sánchez E, RodríguezAcosta A (2011) The association of Triatoma maculata (Ericsson 1848) with the gecko Thecadactylus rapicauda (Houttuyn 1782) (Reptilia: Squamata: Gekkonidae): a strategy of domiciliation of the Chagas disease peridomestic vector in Venezuela? Asian Pacific Journal of Tropical Biomedicine 1(4):279-284. http://doi.org/10.1016/S2221-1691(11)60043-9

Romaña C, Pizarro J, Rodas E, Guilbert E (1999) Palm trees as ecological indicators of risk areas for Chagas disease. Transactions of the Royal Society of Tropical Medicine and Hygiene 93(6):594-595. Retrieved from http://search.ebscohost.com/lo gin.aspx?direct=true\&db=edselc\&AN=edselc.2-52.0-0033398073 \&lang $=$ es\&site $=$ eds-live

Salaverry O (2010) Interculturality in health. Revista Peruana de Medicina Experimental Y Salud Pública 27(1):80-93. http://doi. org/10.1590/S1726-46342010000100013

SantoDomingo AF (2011) Sistema cultural y uso del territorio en la vereda multicultural el Madroño, bajo río Caquetá, Amazonas, Colombia: Pontificia Universidad Javeriana

Spiegel JM, Breilh J, Beltran E, Parra J, Solis F, Yassi A, Rojas A, Orrego E, Bonnie H, Bowie W, Pearce L, Gaibor J, Velazquez P, Concepción M, Parkes M (2011) Establishing a community of practice of researchers, practitioners, policy-makers and communities to sustainably manage environmental health risks in
Ecuador. BMC International Health and Human Rights 11(2):17

Valdez-Tah A, Huicochea-Gómez L, Ortega-Canto J, Nazar-Beutelspacher A, Ramsey JM (2015) Social representations and practices towards triatomines and chagas disease in calakmul, México. PLOS ONE 10(7):1-28. http://doi.org/10.1371/journal. pone. 0132830

Van der Hammen MC, Frieri S, Zamora NC, Navarrete MP (2012) 2. Autodiagnóstico: reflexionar para conocer el territorio. In Herramientas para la formación de contextos interculturales. Bogotá: Servicio Nacional de Aprendizaje, Tropenbos Internacional Colombia, NUFFIC-NPT.

Vásquez C, Robledo S, Callle J, Triana O (2013) Identificación de nuevos escenarios epidemiológicos para la enfermedad de Chagas en la región Momposina, norte de Colombia. Biomédica 33(4):4-10. http://doi.org/10.7705/biomedica.v33i4.836

Victorino I (2007) Historia de apropiación territorial y su relación con el uso y manejo actual y futuro de la comunidad plurietnica de Camaritagua, La Pedrera-Amazonas: Pontificia Universidad Javeriana

Waleckx E, Camara-Mejia J, Ramirez-Sierra MJ, Cruz-Chan V, Rosado-Vallado M, Vasquez-Narvaez S, Najera-Vazquez R, Gourbiére S, Dumonteil E (2015) An innovative ecohealth intervention for Chagas disease vector control in Yucatan, Mexico. Transactions of the Royal Society of Tropical Medicine and Hygiene 109:143-149

Wesolowski A, Eagle N, Tatem AJ, Smith DL, Noor AM, Snow RW, Buckee CO (2012) Quantifying the impact of human mobility on malaria. Science (New York, N.Y.) 338(6104):267270. http://doi.org/10.1126/science.1223467

World Health Organization. (2002). Control of Chagas disease second report of the WHO expert committee. Geneva. Retrieved from http://apps.who.int/iris/bitstream/10665/42443/1/WHO_ TRS_905.pdf

Yukich JO, Taylor C, Eisele TP, Reithinger R, Nauhassenay H, Berhane Y, Keating J (2013). Travel history and malaria infection risk in a low-transmission setting in Ethiopia: a case control study. Malaria Journal 12(1):33. http://doi.org/10.1186/1475-2875-12-33 